\title{
The Inclusion of Microclimate Modelling for House Heating Energy Simulation in Wellington, New Zealand
}

wendy sunarya ( $\nabla$ wendy.ar@upnjatim.ac.id )

Universitas Pembangunan Nasional Veteran Jatim

Nigel Isaacs

Victoria University of Wellington

Michael Robert Donn

Victoria University of Wellington

\section{Research Article}

Keywords: Site, Microclimate, ENVI-met, Building Energy Simulation, Model Validation, Integrated Simulation

Posted Date: July 13th, 2021

DOI: https://doi.org/10.21203/rs.3.rs-673960/v1

License: (c) (i) This work is licensed under a Creative Commons Attribution 4.0 International License. Read Full License 


\section{Abstract}

Site is an important factor in determining building design strategies for responding to the local climate and minimizing energy use. Nevertheless, too often Building Energy Simulation (BES) supporting the design process uses a generic weather file from the local weather station rather than a site-specific microclimate. This study tests the inclusion of microclimate model, ENVI-met, for BES (EnergyPlus) to assess the impact of site parameters on house heating energy in Wellington (New Zealand) where micro-climates vary widely due to the local topography. The ENVI-met model validation was conducted with the air temperature difference of less than $0.5^{\circ} \mathrm{C}$ on average between simulated and measured data in ENVI-met model validation. The validation determines ENVI-met input settings for the integrated simulation with BES for site modelling. The integrated simulation test produced insignificant energy impacts for almost all parameters tested, but it has limitations in modelling slopes. This finding suggests that ENVI-met is not applicable for house heating energy simulation in hilly region.

\section{Introduction}

Site is an important factor in the process of planning and designing a building. In early stage of the design process, site analysis is central to determining how a building should respond to the local climate. From a bioclimatic-design perspective, site analysis is fundamental when choosing design strategies for heating, cooling and natural lighting (Leskovar and Premrov 2013).

Building Energy Simulation (BES) considers site as an important factor. It uses a weather file that represents the site location taken from a nearby weather station, often located at a nearby airport. However, the weather-station microclimate can differ from the site-specific microclimate. Site parameters such as slope, ground surface and vegetation can affect the local microclimate, and mostly they are not considered in BES. The consequences of this are unknown in energy calculation.

In the context of Wellington, New Zealand, micro-climates vary widely, as they are strongly influenced by the local topography (NIWA 2014). Wellington houses can be sited on the hillside in different altitude and orientation. They are likely to have different access to sun, wind, and air temperature, which all strongly influence the building's energy heating consumption. It is reported that $34 \%$ of the total energy use of New Zealand homes is for space heating (Isaacs, Camilleri and French, et al. 2006) while there is no effort for space cooling, especially in Wellington which is generally windy with mild temperatures (Donn and Thomas 2010). Thus, microclimate can strongly influence heating energy requirements in Wellington homes.

This research investigates the importance of site on house-heating-energy simulation in the Wellington context by the inclusion of microclimate modelling using ENVI-met software for BES in EnergyPlus. ENVImet is designed to simulate surface-plant-air interactions(ENVI_MET 2018) and used to generate site microclimate data such as hourly air temperature and Relative Humidity $(\mathrm{RH})$. Numerous studies have shown the capability of ENVI-met for assessing the impact of site parameters on outdoor microclimates, such as the ground-surface and building-facade material(f. Salata, et al. 2015) (Yang, et al. 2012); greenspace(Kong, et al. 2016) (Skellhorn, Lindley and Levermore 2014); tree(Berardi, Jandaghian and 
Graham 2020)(Morakinyo and Lam 2016)(Morakinyo, et al. 2016) and urban form(Gobakis and Kolokotsa 2017) (Taleb and Abu-Hijleh 2013) (Middel, et al. 2014). Among those, two studies had demonstrated the integration of EnergyPlus and ENVI-met - Yang, et al. (2012) modelled the impact of nearby buildings and greenery on building energy consumption in an urban context, while Morakinyo, et al. (2016) assessed the effect of tree shade on indoor thermal conditions. They suggested that the integration of the two software can be a possible solution to quantify the microclimate effect on building indoor climate and energy use. Meanwhile, study by Gobakis \& Kolokotsa (2017) used a different BES software (ESP-r) for an integrated simulation with ENVI-met to evaluate the impact urban environment on building energy consumption and indoor climate.

In terms of site modelling, EnergyPlus cannot simulate the impact of terrain on air temperature and $\mathrm{RH}$ due to: slope inclination and orientation; material of ground surface and nearby buildings; and tree contributing evaporation (Sunarya, Isaacs and Donn 2018). The integrated simulation demonstrated by Yang, et al. (2012) solves EnergyPlus limitation by replacing the original air temperature, dew point temperature and relative humidity in EnergyPlus weather data (epw) with those produced by ENVI-met. The same principle was also applied by Gobakis \& Kolokotsa (2017) for the integrated simulation. The two studies (Gobakis and Kolokotsa 2017) (Yang, et al. 2012) also developed Convective Heat Transfer Coeeficient (CHTC) calculation based on microclimate simulation to replace $\mathrm{CHTC}$ calculation in BES.

This research focuses on the site parameters impact on ambient air temperature change that can affect BES calculation (EnergyPlus) through weather-data modification based on ENVI-met simulation. According to EnergyPlus documentation (U.S. Department of Energy 2016), the hourly air temperature in weather data is an important factor as it affects the calculation for convective heat flux at the exterior surface and infiltration in EnergyPlus simulation. From previous ENVI-met model studies, there two important questions related to the use of ENVI-met for BES:

1. How to validate ENVI-met model for BES. Previous studies validated the ENVI-met model by analysing the Index agreement $(d)$ and/or Correlation Coefficient $\left(R^{2}\right)$ of the simulated and measured temperature data. Salata, et al. (2016) reports on studies validating the ENVI-met model with such an approach. Most of those studies stated that the model is validated if the simulated and measured data had "good" correlation or agreement mostly with a $\mathrm{d}$ or $\mathrm{R}^{2}$ value of more than 0.8 . But it is unknown whether such correlation produces a difference in air temperature affecting the energy calculation significantly. So, an important question is how the acceptable difference between measured and simulated should be.

2. How to develop a practical and effective integrated simulation between ENVI-met and EnergyPlus. ENVImet is based on grid cells for the 3D environment model and the microclimate data can be produced in each grid cell by using a "receptor". The weather file modification for integrated simulation by Yang, et al. (2012) is based on an averaged value from receptors along the whole building envelopes, which could be redundant for output data extraction. Also, the air temperature on the site can be different in orientation, which can influence the building differently in different parts. 
This study attempts to validate the ENVI-met model for BES purpose and test the integrated model in different site scenarios to determine which are the most important site parameters in the energy simulation process.

\section{Method}

\subsection{ENVI-met model validation}

ENVI-met model validation aims to determine reliable input settings for ENVI-met, which can be applied further for integrated simulation testing different site scenarios using hypothetical model. This study used ENVI-met basic (free) version (V.4.4), but within the ENVI-met basic $50 \mathrm{~m}$ by $50 \mathrm{~m}$ horizontal area to generate the local air temperature. The main limitation of ENVI-met in generating local microclimate is that it only produces 24 hours of microclimate output in one simulation. This study is based on a one-day simulation which can be the first step to examine the importance of site parameters.

The validation used the site of Kelburn Weather station as a case study. The measured data of hourly air temperature was obtained through NIWA for the comparison with simulated data produced by ENVI-met. The Kelburn weather station is in a garden area and surrounded by suburbs (see Fig. 1) - the weather station device is relatively unobstructed within a radius of $20 \mathrm{~m}$.

The date of 5th June 2016 was set for simulation, which is a sunny day in the winter season and enable to match the default ENVI-met solar radiation - ENVI-met basic version cannot model the diurnal change of solar radiation influenced by the change of cloud cover. The default ENVI-met solar radiation has a similar value of global radiation with the measured data but different in both direct and diffuse solar radiation values (Fig. 2).

Default Wellington geographical location (latitude and longitude) was set. The grid-cell size of $1 \mathrm{~m} \times 1 \mathrm{~m} x$ $1 \mathrm{~m}$ is applied as it is the finest resolution available in ENVI-met, which allows the measurement receptor to capture the finest scale of microclimate data (within $1 \mathrm{~m}^{2}$ horizontal grid) in the specific location on the site model. The number of grid cells of $50 \times 50 \times 25(x, y, z)$ was set, so the domain area of the model covers the horizontal area of $50 \mathrm{~m} \times 50 \mathrm{~m}$ with a height of $25 \mathrm{~m}$. Forced LBC (Lateral Boundary Condition) was applied, where the hourly air temperature and relative humidity on 5th June 2016 was inputted (forced) to the simulation model via the ENVI-met simple forcing tool. The wind system in ENVI-met does not heat or cool the atmosphere (Middel, et al. 2014) and thus the wind input (wind speed and direction, and surrounding surface roughness value) does not affect the simulated air temperature. The wind speed was set to $0.8 \mathrm{~ms}^{-1}$ (not windy) to avoid any technical error (unstable turbulence-model calculation) during simulation initialization, while the wind direction and roughness values were set at defaults of $0^{\circ}$ and 0.1 respectively. Some studies (Middel, et al. 2014) (Skellhorn, Lindley and Levermore 2014) suggested to input additional hours for simulation duration as start-up time for improving the model results and stability. The model validation applies and tests the 72-hours duration which is recommended by Skellhorn, et al. (2014) and was applied by previous studies (Morakinyo, et al. 2016) (F. Salata, et al. 2016), starting from 00.00, and only analyses only the last 24 hours. 
The figure below (Fig. 3) shows the site area $(50 \mathrm{~m} \times 50 \mathrm{~m})$ of Kelburn weather station (Left), and the ENVI-met site model for the Normal model (Middle) and Calibrated model (Right). The grey colour represents building objects and most of them are $3 \mathrm{~m}$ in height. The white block is the asphalt area while the grass is depicted by the light green bocks. The pure green depicts the tree objects with a height of $8 \mathrm{~m}$ in the model (simplified) which are in the north and southeast area of the Normal model. A receptor is in the middle of the site model.

The simulated and measured data must be comparable to validate the ENVI-met model. Some previous studies (Morakinyo, et al. 2016) (f. Salata, et al. 2015) (Skellhorn, Lindley and Levermore 2014) generated a comparable simulated data by creating a specific site model in ENVI-met which inputs generic microclimate data (nearby weather station). The simulated data has taken account of modelled site parameters in ENVImet while the on-site measured data has been affected by nearby site parameters in real condition.

However, the model validation in this research conducts a different approach by comparing the real and modelled weather-station by considering the calibrated model comparable to the real data. As shown in the Fig. 2, direct solar radiation generated by ENVI-met is much higher than the real condition. The north trees in the Normal model (middle) can block the solar radiation during the daytime, which can lead the simulation to produce cooler air temperature than the measured data. In this case, the Normal model applied forced LBC inputting the hourly temperature and $\mathrm{RH}$ from the measured data (weather station) which have been affected by tree shades in real condition. In other words, the simulated data of the Normal model (middle) is affected twice by the north-trees shading, and this is not comparable with reality.

\subsection{Integrated simulation for investigating site impact 2.2.1. Hypothetical EnergyPlus house model}

EnergyPlus 8.6 was used to develop the hypothetical house model to assess the impact of local air temperature change from ENVI-met site modelling on energy calculation. The hypothetical house model with a $10 \mathrm{~m} \times 10 \mathrm{~m}$ plan area and $3 \mathrm{~m}$ in height (2.5m for the occupant zone and $0.5 \mathrm{~m}$ for the celling zone) was created in EnergyPlus. The four thermal zones are orientated to the outdoor microclimate: (1) North zone; (2) West Zone; (3) South Zone; and (4) East Zone (Fig. 4). The EnergyPlus simulation used four modified weather files produced by ENVI-met in four different directions (North, East, South and West). For example, the heating-load calculation of the North zone was analysed after using a modified weather file based on outdoor microclimate generated by receptor (R01) placed on the north side in ENVI-met. This analysis similarly applies to other zones.

The EnergyPlus model development is validated by applying the relevant building compliance and method used in New Zealand. The insulation value of the construction complies with the NZBC (New Zealand Building Code requirements), Clause H1, which uses NZS (New Zealand Standard) 4218:2009 appropriate for the Wellington location. The internal gain inputs (lighting, equipment and occupancy) are based on those used in ALF (BRANZ 2007) -a method for determining the Building Performance Index (BPI) which in turn can be used to demonstrate compliance with NZBC Clause $\mathrm{H} 1$. The model is assumed to house four people or one person in each external zone. 
Heating and natural ventilation setpoints are based on the Modelling Method, clause 4.3 NZS 4218:2009. The heating period was based on the results from the Household Energy End-use Project (HEEP) (Isaacs, Camilleri and Burrough, et al. 2010) and the monitoring report (Burrough 2010). The ventilation airflow rate was defined by the EnergyPlus natural ventilation input: 'WindandStackOpenArea' object, where the flow rate is determined by wind speed and the thermal stack effect along with the area of the opening (U.S. Department of Energy 2016). For that input, the openable area for natural ventilation was set to $5 \%$ of the total area per each zone $\left(1.25 \mathrm{~m}^{2}\right)$ with the fraction of 0.125 of the total openable area, which is based on the minimum requirement of NZBC Clause G4 Ventilation (Ministry of Business, Innovation and Employment NewZealand 2008) and scheduled to be open from $7 \mathrm{am}$ to $11 \mathrm{pm}$. The total window area is $11.6 \%$ of the total area of exterior walls, complying with the limitations of the NZS4218 Modelling Method of being no more than 30\% (Ministry of Business, Innovation \& Employment 2015)

\subsubsection{ENVI-met settings and site scenarios}

As stated earlier, ENVI-met input settings (Grid size, simulation duration, etc.) for the integrated simulation is based on the determination from model validation. ENVI-met forced LBC was based on generic weather file of Wellington (WN 934360) obtained online on the EnergyPlus website. The date of 23rd June (winter) was set for simulation with a clear-sky condition - to match the default ENVI-met sky easily. These settings can give an answer of whether a generic weather file can be used for site modelling in ENVI-met to produce a reliable site-specific microclimate.

The house model dimensions in ENVI-met are the same as that used in EnergyPlus (10m $x 10 \mathrm{~m}$ with a height of $3 \mathrm{~m}$ ) and is in the centre of the domain area. A receptor is set in front of each middle façade (four in total) and records microclimate data in grid centroid (the grid size of $1 \mathrm{~m}$ ), which is $0.5 \mathrm{~m}$ from building façade with the level of $1.5 \mathrm{~m}$ from the ground (the centroid of building surface). The Base model site has no obstruction (open-flat) and is surrounded by "loamy soil" (default soil condition). Figure 5 (left) illustrates the Base model site. 
Table 1

summarizes the twelve site scenarios used in ENVI-met for investigating the site impact.

Those scenarios were established based on the site parameters that are not considered in EnergyPlus:

\begin{tabular}{|c|c|c|}
\hline Site parameters & Scenario & \\
\hline \multirow[t]{3}{*}{ Ground Surface } & Base model & (1) Loamy Soil \\
\hline & \multirow[t]{2}{*}{ Pavement } & (2) Full Pavement \\
\hline & & (3) Pavement on the Eastside \\
\hline \multirow[t]{2}{*}{ Slope } & Equatorial facing & (4) Facing-north slope $\left(45^{\circ}\right)$ \\
\hline & Non-equatorial facing & (5) Facing-south slope $\left(45^{\circ}\right)$ \\
\hline \multirow[t]{3}{*}{ Vegetation } & \multirow[t]{2}{*}{ Number of Tree } & (6) 12 trees in all directions ( $10 \mathrm{~m}$ of height) \\
\hline & & (7) 60 trees in all directions (10m of height) \\
\hline & Leaves & (8) 60 trees -Double LAD (Leaf Area Density) \\
\hline \multirow[t]{4}{*}{ Buildings } & \multirow[t]{2}{*}{ Building shade } & (9) Buildings in all direction (3m height) \\
\hline & & (10) Nearby buildings (6m height) \\
\hline & \multirow[t]{2}{*}{ Building surface } & (11) Nearby buildings ( $3 \mathrm{~m}$ height) high albedo \\
\hline & & (12) Nearby buildings ( $3 \mathrm{~m}$ height) concrete \\
\hline
\end{tabular}

Table 1 Site scenarios for the integrated simulation

(brown) and dark pavement (grey). Scenario 2 and 3 investigate the impact of the heating effect from the ground surface (pavement) while Scenarios 4 and 5 test the impact of the slope. The ENVI-met slope model is an integral part of the grid cell and thus, it consists of vertical and horizontal surfaces each on the $1 \mathrm{~m}$ grid. The Facing-north slope (Scenario 4) was tested to see whether it produces a warmer temperature due to the surface inclination facing the equator (Olgyay 1963), while under this scenario the Facing-south slope (Scenario 5) is expected to reduce outdoor air temperature during the day due to shading.

Figure 6 shows the site scenarios for vegetation and nearby buildings. The vegetation scenarios test the impact of trees (Scenarios 6 and 7) and tree-leaf density (Scenario 8). For nearby building cases, the impact of building height (Scenarios 9 and 10) and the building's façade material (Scenarios 11 and 12) are tested. The surface reflection value for both Scenarios 9 and 10 is 0.4 while for the high albedo surface is 0.7 (Scenario 12). Scenario 11 applies concrete material to the surrounding buildings with the ENVI-met provided 0.6 reflection value.

\section{Results And Discussion}

\subsection{ENVI-met validation and settings determination}


As would be expected, the normal model produces the cooler air temperature while the results of the calibrated model are much closer to the measured data (See left, Fig. 7). As discussed earlier, the lower air temperature in the normal model is likely due to the north tree objects and this result is not comparable with weather station data - The simulation applied the measured data of the weather station that has been affected by the tree shading.

The Normal model produces similar values to the measured data in the first ten hours with an average gap of $0.25^{\circ} \mathrm{C}$. The biggest gap is around midday ( $11 \mathrm{am}$ to $2 \mathrm{pm}$ ), by an average of $0.8^{\circ} \mathrm{C}$, and it narrows to be $0.5^{\circ} \mathrm{C}$ from $3 \mathrm{pm}$ to $11 \mathrm{pm}$. Meanwhile, the calibrated model has higher figures than the weather station before $8 \mathrm{am}$, by $0.2^{\circ} \mathrm{C}$ on average. The lower air temperature by an average of $0.35^{\circ} \mathrm{C}$ occurs from 11 am to $2 \mathrm{pm}$ and it becomes closer to the measured data $\left(0.15^{\circ} \mathrm{C}\right.$ on average) until midnight.

According to several studies (Kanopacki 1996) (Taha, et al. 1997), the air temperature difference of $1-2^{\circ} \mathrm{C}$ during the daytime (around $2 \mathrm{pm}$ ) can impact energy-saving for cooling by $10 \%$. Another study (Ca, et al., 1998) found that the difference of $2^{\circ} \mathrm{C}$ from midnight to 8 am can reduce the energy for cooling by $15 \%$. Additionally, the average temperature reduction by $1^{\circ} \mathrm{C}$ also equals the cooling effect produced by parks (Bowler, et al. 2010). Thus, the average gap of $0.8^{\circ} \mathrm{C}$ in the midday from the simulation of the Normal model can be considered significant as it can significantly affect the calculation results in energy simulation. Meanwhile, the results of the calibrated model are closer to the measured data with an average difference of $0.35^{\circ} \mathrm{C}$ in the midday, which confirms that the calibrated model is comparable to the measured data and the basic input settings applied in the model validation are reliable to use for further simulation. This also suggests that the acceptable difference of air temperature between for ENVI-met model validation should be less than $0.5^{\circ} \mathrm{C}$.

The model validation also compares the simulation results of each iterative day (every 24 hours) to evaluate whether the simulation duration of 72 hours is effective for the simulation (See right, Fig. 7). The hourly data of the second (D2) and the third day (D3) is relatively the same while the first day (D1) is significantly different in earlier hours. It takes eight hours for the D1 to produce similar results to the other days, by the difference of less than $0.1^{\circ} \mathrm{C}$. Also, the differences in hourly temperature between 6 am to 8 am on the first day is no more than $0.5^{\circ} \mathrm{C}$, which can be considered insignificant for affecting energy calculation results. Thus, the simulation duration can be reduced by up to 30 hours for the most efficient computational time.

The model validation determines ENVI-met settings (see Table 2) which are considered reliable to apply for the integrated simulation. These settings produce the simulated data with the acceptable difference of no more than $0.5^{\circ} \mathrm{C}$ on average compared to the measured data, which does not affect the energy calculation results significantly. 
Table 2

ENVI-met input settings determination

\begin{tabular}{|c|c|c|}
\hline & Grid Size & 1mx1mx1m $(x, y, z)$ \\
\hline & Domain Area (cells) & $50 \times 50 \times 25$ \\
\hline & Simulation Duration & $30 \mathrm{~h}$ \\
\hline & Starting time simulation & 18.00 \\
\hline & Wind Speed & $0.8 \mathrm{~ms}^{-1}$ \\
\hline & Wind Direction & $0^{\circ}$ (Default) \\
\hline & Roughness value & 0.1 (default)) \\
\hline & Soil type & Loamy soil (Default) \\
\hline & Sky condition & Clear sky (Default) \\
\hline 3.2. Integrated s & mulation & \\
\hline
\end{tabular}

The evaluation for the ENVI-met hypothetical model is also conducted to ensure whether the applied input setting (Table 2) is reliable to use - to double-check the input settings. The microclimate data of the Base model (open-flat) is generated by a single receptor placed in the middle of the model. As the site modelled in ENVI-met is an open-flat area with loamy soil on the ground surface, the model is expected to produce similar microclimate data as the generic weather file of Wellington. Figure 8 compares the hourly air temperature and heating load on 23rd June between the EnergyPlus model using the default (generic) weather file and that using ENVI-met.

There is an average difference of $0.5^{\circ} \mathrm{C}$ between the default-weather and the ENVI-met-based model in the first eight hours (0:00 to 08:00) and after daytime (18:00 to 24:59). During the day (08:00 to 18:00), both models are similar to the difference averaging $0.1^{\circ} \mathrm{C}$. The total heating load of the default-weather model is 10,591 Wh while the ENVI-met-based model consumes 11,580 Wh or $5.7 \%$ more. Such air-temperature difference has no significant consequences on the results of house heating energy modelling in the Wellington context, which is also like literature review findings (Sect. 3.1). The open-flat site ENVI-met model is considered to produce a similar result to that from the weather file and thus, the model input settings are reasonable to use.

\subsubsection{Integrated simulation for site scenarios}


Table 3

shows the total house heating energy (sum of North, East, South and West zones) for the 12 site scenarios.

Significant changes in heating energy use are seen only in Scenario 2 and 5 (Full pavement and Facingsouth slope) while other scenarios produced very similar results to the base model (Scenario 1), with differences from $-3.6 \%$ to $+1.0 \%$.

$\begin{array}{lll}\text { Scenario } & \begin{array}{l}\text { Total Energy for all four zones } \\ \text { (wh) }\end{array} & \begin{array}{l}\text { Difference to base } \\ \text { (\%) }\end{array}\end{array}$

(1) Base model (Open-flat, loamy soil) 11,546 N/A

(2) Full pavement

10,210

$-11.6 \%$

(3) Pavement on the east side

11,126

$-3.6 \%$

(4) Facing-north slope

11,665

$1.0 \%$

(5) Facing-south slope

10,624

$-8.0 \%$

(6) 12 trees in all direction

11,382

$-1.4 \%$

(7) 60 trees in all direction

11,277

$-2.3 \%$

(8) 60 trees- Double LAD

11,213

$-2.9 \%$

(9) Nearby buildings ( $3 \mathrm{~m}$ height)

11,428

$-1.0 \%$

(10) Nearby building ( $6 \mathrm{~m}$ height)

11,480

$-0.6 \%$

(11) Nearby buildings (3m height) -High

11,359

$-1.6 \%$

Albedo

(12) Nearby buildings (3m height) -Concrete

11,608

$-4.1 \%$

Table 3 House heating energy (23rd June) based on 12 site scenarios from ENVI-met

Changing the ground surface from loamy soil to pavement (Scenario 2) has the biggest reduction of heating energy of $11.6 \%$ while Scenario 3 (half pavement) has a 3.6\% reduction (See Table 3 ). The full pavement has on average $1^{\circ} \mathrm{C}$ warmer temperature than the Base model in all receptors, while the half pavement is warmer only in the east receptor (a2 - paving side) by an average of $0.6^{\circ} \mathrm{C}$ (See Fig. 9). ENVI-met thus produces the same impacts as those reported in the literature findings as to the heating effect of the ground surface (asphalt or pavement) on the local air temperature (Bowler, et al. 2010) and building energy consumption (Kanopacki 1996) (Taha, et al. 1997) (Ca, Asaeda and Abu 1998).

The facing-north slope (Scenario 4$)$ has a similar energy use (+ $1 \%$, See Table 3$)$ and hourly air temperature as the base model (see Fig. 10), which indicates that the equatorial facing slope in the ENVI-met model does not heat ambient temperature, which is unlike that suggested by Olgyay (1963). On the other hand, the nonequatorial facing (south) slope (Scenario 5) uses $8.0 \%$ less house heating energy than the Base model. It has cooler air temperature during the daytime averaging $1{ }^{\circ} \mathrm{C}$ but warmer air temperature during the dark hours ( $6 \mathrm{pm}$ to $6 \mathrm{am}$ ) by $1^{\circ} \mathrm{C}$ on average. This means the heating-load reduction in the facing-south slope is due to the night-time warmer temperature. 
All tree scenarios (Scenario 6, 7 and 8) did not produce a large change of heating load compared to the Base model (no more than 2.9\%) and has warmer air temperature than the open-flat site model during the daytime. These results do not match the literature about the cooling effect of tree shade (Goulding, Lewis and Steemers 1992) and evapotranspiration (Berner, Berner and Moulton 2005). Additionally, the results are unlike those from previous ENVI-met model study findings that a tree model reduces the ambient air temperature (Berardi, Jandaghian and Graham 2020) (Kong, et al. 2016) (Skellhorn, Lindley and Levermore 2014) and affects the calculation of indoor air temperature in EnergyPlus (Morakinyo, et al. 2016). The results of model validation are also contradictive with tree-scenario simulated data, where the Normal model with tree models on the north side produced cooler temperature than the Calibrated model (without the tree).

All nearby-buildings scenarios (Scenarios 9-12) produced an insignificant impact on the heating load compared to the Base model (See Table 3). Scenarios 9 and 10 show that the increase of building height reduced the outdoor air temperature, especially on the north side of the building (see a1 in Fig. 12), most likely due to the increase of building shade. Changing the building's façade to have a higher albedo or use concrete material (Scenario 11 and 12), also has a small effect on the heating load (no more than 4.1\%).

The results of the integrated simulation reveal that most of the site parameters modelled in ENVI-met do not produce the impact as suggested by the literature, which is summarised and discussed below:

1. Slope impact. The Facing-north (equatorial) slope does not heat the ambient temperature and reduces energy use, while the Facing-south slope leads to the air temperature increasing by an average of $1^{\circ} \mathrm{C}$ during the night-time, reducing energy use by $8.0 \%$. Discussions on the online ENVI-met forum revealed that the vertical surfaces of a slope do not interact with the microclimate system as it is an artificial surface due to the grid structure (ENVI-met Forum 2018). This confirmation explains why the northfacing slope ENVI-met does not heat the ambient air temperature as expected (Olgyay 1963). The facing-south slope increasing the air temperature during the night-time is also unexpected. There is no explanation from the literature, and it is unlikely that a slope not exposed to the sun during the day (non-equatorial facing) will be warmer. This suggests that ENVI-met is limited to generate the microclimate resulting from a slope.

2. Tree impact. The tree model produces a contrary impact to the literature findings and model validation, which slightly lead to warmer air temperature, instead of providing cooling through shade and evapotranspiration. There are two possibilities of this contradictive result. First, the previous ENVI-met model studies were based in locations with warm or hot weather (ambient air daytime temperature over $25^{\circ} \mathrm{C}$ ), and thus, they could produce a significant impact in reducing the ambient air temperature. The study case of Morakinyo, et al. (2016) was in Nigeria (tropical climate), while Skellhorn, et al. (2014) and Kong, et al. (2016) respectively used Manchester (UK) and Nanjing (China) summer season. Meanwhile, this study is based on the winter season in Wellington (New Zealand), with air temperature ranging from 6 to $12^{\circ} \mathrm{C}$ (NIWA 2014), which might lead ENVI-met tree model behave differently. One study (Bande, et al. 2019) also reported a minor impact of ENVI-met tree model in several trials and found that ENVI-met simulation results are better in spring and summer than in the winter. Second, the difference of tree impact between the hypothetical and real case model (See Fig. 3, middle) suggests that the tree configuration or building object in ENVI-met can be a factor for this contradictive result. 
The site of the real case model is obstructed by the large tree area on the north side with $18 \mathrm{~m}$ far from the receptor. Meanwhile, the four receptors in the hypothetical model are surrounded by smaller trees with closer distance (see Fig. 6) and near building façade $(0.5 \mathrm{~m})$ which might heat the surrounding ambient temperature. This means that the receptor location is an important consideration for the effective assessment of site parameters impact - As microclimate data produced by ENVI-met vary in space and time.

3. The impact of nearby buildings. The nearby buildings do not have a significant impact on air temperature change in ENVI-met modelling for the winter season. This finding is similar to a study using ENVI-met (Taleb and Abu-Hijleh 2013) finding that urban configuration (nearby buildings) can lead to cooler temperature in summer and autumn, but not in winter. A study by Middel, et al. (2014) also showed that urban forms can lead to a summer temperature decrease of $2^{\circ} \mathrm{C}$. This suggests that the cooling effect of building shade in ENVI-met can be significant for the hot weather condition, especially in an urban context where buildings are taller. Thus, the insignificant impact of nearby buildings in the integrated simulation testing is likely due to the cold climate of the winter season in Wellington and the height of the building model which are relatively short ( $3 \mathrm{~m}$ and $6 \mathrm{~m})$. Additionally, a concrete surface on nearby buildings (Scenario 12) has the biggest impact on heating load reduction compared to other nearby-building scenarios, suggesting that the heating effect of the building surface can be significant in the case of the urban context where the concrete material is largely applied on building façade.

\section{Conclusion}

The ENVI-met model validation in this study produced the air temperature difference of less than $0.5^{\circ} \mathrm{C}$ on average between simulated and measured data, which was considered acceptable to include ENVI-met model for the integrated simulation with EnergyPlus - as it has no significant consequences on heating energy consumption. Then, the model validation determines a standard input setting that can be applied for efficient and reliable ENVI-met simulation (basic version) for the winter context.

The results of the integrated simulation reveal that the ENVI-met model generally produces insignificant impacts of site parameters on modelled house heating energy in the Wellington winter. The ground-surface material is the only parameter that significantly influenced the outdoor air temperature, averaging a $1^{\circ} \mathrm{C}$ increase and reducing house heating energy use by up to $11.6 \%$. It is suggested that the insignificant impact of other parameters is due to the cool weather condition (winter season) regarding the previous ENVI-met studies producing a significant impact based on summer or warmer temperature sessions. In this case, the nearby tree and building models can behave differently in the winter compared to summer - their shade does not further cool the already cool ambient temperature. Additionally, the research has shown that ENVImet has limitations in modelling slopes. While the modelled slope can block solar radiation, its vertical surface does not interact with the microclimate system in ENVI-met and cannot produce warmer ambient temperature in equatorial-facing slope.

The insignificant impact of site parameters suggests that the idea of microclimate modelling using ENVImet basic (free) version for site modelling in BES is not applicable for house heating energy calculation. 
Reflecting on previous studies using ENVI-met, microclimate modelling is useful in generating or predicting the impact of built-environment elements for an urban context in hot or warm weather conditions. The study also found an insignificant contrary impact of tree in ENVI-met, which are likely due to receptor location near the building façade - it warms the ambient air temperature near the facade. This suggests that the effective assessment of site parameters impact cannot be based only on ENVI-met microclimate from several receptors (near-façade). The important questions related to this issue is that is how the ENVI-met receptors can be properly placed in site modelling and how its microclimate data should be analysed for an effective assessment. These questions can be explored in further studies.

\section{Limitation}

The integrated simulation test in this study is based on a one-day simulation on clear-sky condition as ENVImet can only produce one-day microclimate data in one simulation with a long computational time (6 to 7 hours for one simulation in this study by using PC with Intel Core i7 processor and 16 GB RAM). In this case, it is limited to only set solar radiation based on the multiplier factor from 1.0 (clear sky) to 0.0. The solarradiation limitation is solved in the newest ENVI-met version providing a full-forcing feature to input solar radiation based on the weather data (ENVI_MET 2019). This new feature allows ENVI-met to produce realistic output on various days with different sky condition but, it is not provided by the basic (free) version. Although this study is based on one-day modelling, it gives an initial answer of how the site parameters (that cannot be modelled in EnergyPlus) affect house heating energy simulation.

\section{Declarations}

\section{Acknowledgement}

This study was supported by LPDP scholarship under the Ministry of Finance Indonesia. The data of Wellington weather was obtained from NIWA for the ENVI-met validation process

\section{Funding}

Not Applicable

\section{Conflict of interest}

The authors declare that they have no known competing financial interests or personal relationships that could have appeared to influence the work reported in this paper

\section{Availability of data and material}

The measured data of Wellington Kelburn weather station used for ENVI-met model validation in this study was obtained from NIWA (Wellington) with permission

\section{Code Availability}

Not Applicable 


\section{Ethics Approval}

Not Applicable

\section{Consent to participate}

Not Applicable

\section{Consent for publication}

Not Applicable

\section{References}

Bande, Lindita, Afshin Afshari, Dina Al Masri, Mukesh Jha, Leslie Norford, Alexandros Tsoupos, Prashanth Marpu, Yosha Pasha, and Peter Armstrong. 2019. "Validation of UWG and ENVI-met models in an Abu Dhabi District, based on site measurements." Sustainability 11 (16): 4378.

Berardi, Umberto, Zahra Jandaghian, and Jonathan Graham. 2020. "Effects of greenery enhancements for the resilience to heat waves: A comparison of analysis performed through mesoscale (WRF) and microscale (Envi-met) modeling." Science of the Total Environment (747): 141300.

Berner, E.K., R.A. Berner, and K.L. Moulton. 2005. "Plants and mineral weathering: present and past." Treatise on geochemistry 5 169-188.

Bowler, Diana E, Lisete Buyung-Ali, Teri M Knight, and Andrew S Pullin. 2010. "Urban greening to cool towns and cities: A systematic review of the empirical evidence." Landscape and Urban Planning 147-155.

BRANZ. 2007. ALF - Internal Gains. Accessed 6 2018. http://alf.branz.co.nz/help/internal-gains.

Burrough, Lisa. 2010. "Heat Pumps in New Zealand Houses." 5th Australian Housing Researcher. Auckland.

Ca, Vu Thanh, Takashi Asaeda, and Eusuf mohamad Abu. 1998. "Reductions in air conditioning energy caused by a nearby park." Energy and Buildings (29): 83-92.

Donn, Michael Robert, and Grant Thomas. 2010. Designing comfortable homes: Guidelines on the use of glass, mass and insulation for energy efficiency. Wellington: Cement \& Concrete Association.

ENVI_MET. 2018. ENVI-met 4. A holistic Microclimate Modelling System. http://envi-met.info/doku.php? id=root:start.

—. 2019. "NEW FEATURES -Winter Release 2018/2019." 1 16. Accessed 1 2019. http://envimet.info/doku.php.

ENVI-met Forum. 2018. ENVI-met board. Accessed July 2018. http://www.envi-hq.com/index.php? sid $=8214114 \mathrm{e} 9385 f f 06 \mathrm{~b} 89 \mathrm{c} 9380 \mathrm{a} 9038 \mathrm{b0c}$. 
Gobakis, Kostantinos, and Dionysia Kolokotsa. 2017. "Coupling building energy simulation software with microclimaticsimulation for the evaluation of the impact of urban outdoorconditions on the energy consumption and indoor environmentalquality." Energy and Buildings (157): 101-115.

Goulding, John R., J. Owen Lewis, and Theo C (ed,) Steemers. 1992. Energy conscious design: a primer for architects. London: Batsford for the Commission of the European Communities.

Isaacs, Nigel, Michael Camilleri, Lisa Burrough, Andrew Pollard, Kay Saville-Smith, Ruth Fraser, Pieter Rossouw, and John Jowett. 2010. "Energy Use in New Zealand Households: Final Report on the Household Energy End-Use Project (HEEP)." BRANZ Study Report 221, Porirua.

Isaacs, Nigel, Michael Camilleri, Lisa French, Andrew Pollard, Kay Saville-Smith, Ruth Fraser, Pieter Rossouw, and John Jowett. 2006. Energy Use in New Zealand Househoulds. Porirua: BRANZ.

Kanopacki, S. 1996. Energy and Cost Benefits from Light-Colored Roofs in 11 US Cities. Berkeley: Lawrence Berkeley National Laboratory.

Kong, Fanhua, Changfen Sun, Fengfeng Liu, Haiwei Yin, Fei Jiang, Yingxia Pu, Gina Cavan, Cynthia Skellhorn, Ariane Middel, and Iryna Dronova. 2016. "Energy saving potential of fragmented green spaces due to their temperature regulating ecosystem services in the summer." Applied Energy (183): 1428-1440.

Leskovar, Vesna Žegarac, and Miroslav Premrov. 2013. Energy-efficient timber-glass houses. London: Springer.

Middel, Ariane, Kathrin Häb, Anthony J. Brazel, Chris A. Martin, and Subhrajit Guhathakurta. 2014. "Impact of urban form and design on mid-afternoon microclimate in Phoenix Local Climate Zones." Landscape and Urban Planning 16-28.

Ministry of Business, Innovation \& Employment. 2015. House Insulation Requirements. Accessed 62018. https://www.building.govt.nz/building-code-compliance/h-energy-efficiency/h1-energy-efficiency/buildingcode-requirements-for-house-insulation/house-insulation-requirements/.

Ministry of Business, Innovation and Employment NewZealand. 2008. Acceptable Solution and Verification Method for New Zealand Building Code Clause -G4 Ventilation. Wellington: Ministry of Business, Innovation and Employment.

Morakinyo, Tobi Eniolu, and Yun fat Lam. 2016. "Simulation study on the impact of tree-configuration, planting pattern and wind condition on street-canyon's micro-climate and thermal comfort." Building and Environment (103): 262-275.

Morakinyo, Tobi Enioulu, K.W.D. Kalani. C. Dahanayake, Olumuyiwa Bayode Adegun, and Ahmed Adedoyin Balogun. 2016. "Modelling the effect of tree-shading on summer indoor and outdoorthermal condition of two similar buildings in a Nigerian university." Energy and Buildings 721-732.

NIWA. 2014. The Climate and Weather of Wellington (2nd Edition). New Zealand: NIWA. 
Olgyay, Victor. 1963. Design with climate: bioclimatic approach to architectural regionalism. Princeton University Press.

Salata, ferdinando, lacopo Golasi, Andrea de Lieto Vollaro, and Roberto de Lieto Vollaro. 2015. "How high albedo and traditional buildings' materials and vegetation affect the quality of urban microclimate. A case study." Energy and Building (99): 32-49.

Salata, Ferdinando, Lacopo Golasi, Roberto de Lieto Vollaro, and Andrea de Lieto Volarro. 2016. "Urban microclimate and outdoor thermal comfort. A proper procedure to fit ENVI-met simulation outputs to experimental data." Sustainable Cities and Society 318-343.

Simon, Helge, Jenny Lindén, David Hoffmann, Peter Braun, Michael Bruse, and Jan Esper. 2018. "Modeling transpiration and leaf temperature of urban trees-a case study evaluating the microclimate model ENVI-met against measurement data." Landscape and urban planning (174): 33-40.

Skellhorn, Cynthia, Sarah Lindley, and Geoff Levermore. 2014. "The impact of vegetation types on air and surface temperatures in a temperate city: A fine scale assessment in Manchester, UK." Landscape and Urban Planning 129-140.

Standards New Zealand. 2009. "NZS 4218:2009 Thermal insulation - Housing and small buildings." Wellington: Standards New Zealand.

Sunarya, Wendy, Nigel Isaacs, and Michael Robert Donn. 2018. "The Importance of Site on House Heating Energy Modelling." Architectural Science Association.

Taha, haider, Alan Meier, Weijun Gao, and Toshio Ojima. 1997. "Mitigation of Urban Heat Islands: Meteorology, Energy, and Air Quality Impacts." Japan: international Symposium on Monitoring and management of Urban heat Island.

Taleb, Dana, and Bassam Abu-Hijleh. 2013. "Urban heat islands: Potential effect of organic and structured urban configurations on temperature variations in Dubai, UAE." Renewable Energy (50): 747-762.

U.S. Department of Energy. 2016. Engineering Reference. U.S. Department of Energy.

U.S. Department of Energy. 2016. "Input Output Reference." 42. The U.S. Department of Energy. https://energyplus.net/sites/all/modules/custom/nrel_custom/pdfs/pdfs_v8.7.0/InputOutputReference.pdf.

Yang, Xiaoshan, Lihua Zhao, Michael Bruse, and Qinlin Meng. 2012. "An integrated simulation method for building energy performance assessment." Energy and Buildings 243-251.

\section{Figures}



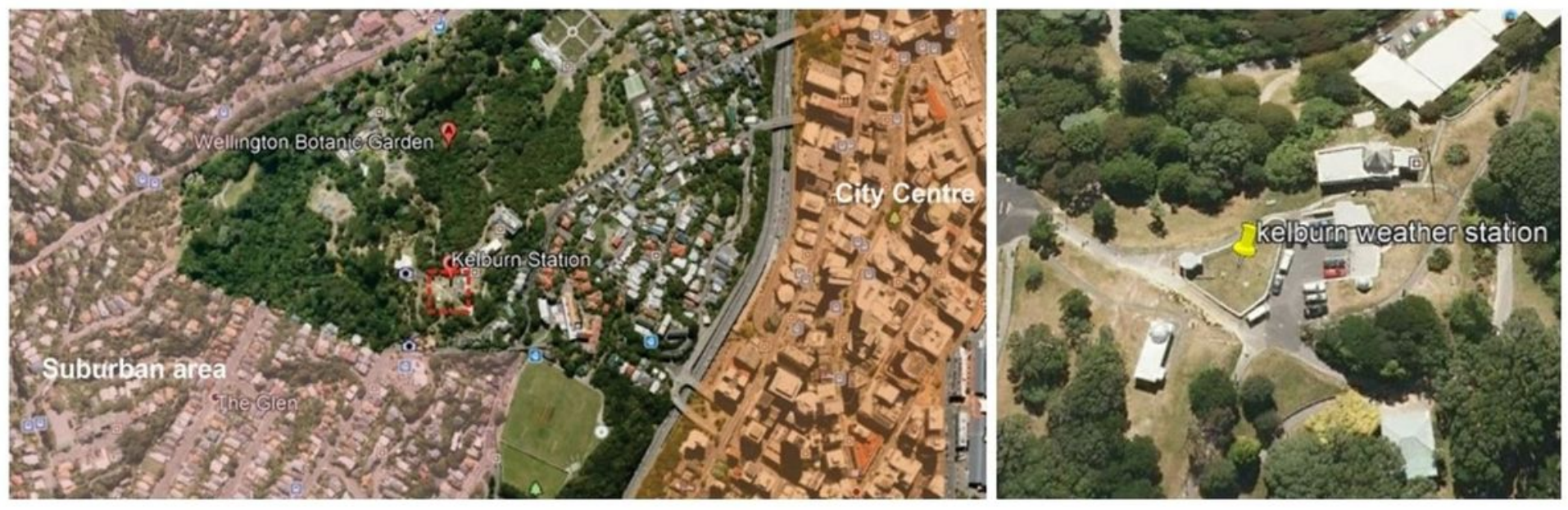

Figure 1

The site of Kelburn Weather station (Via Google Earth)

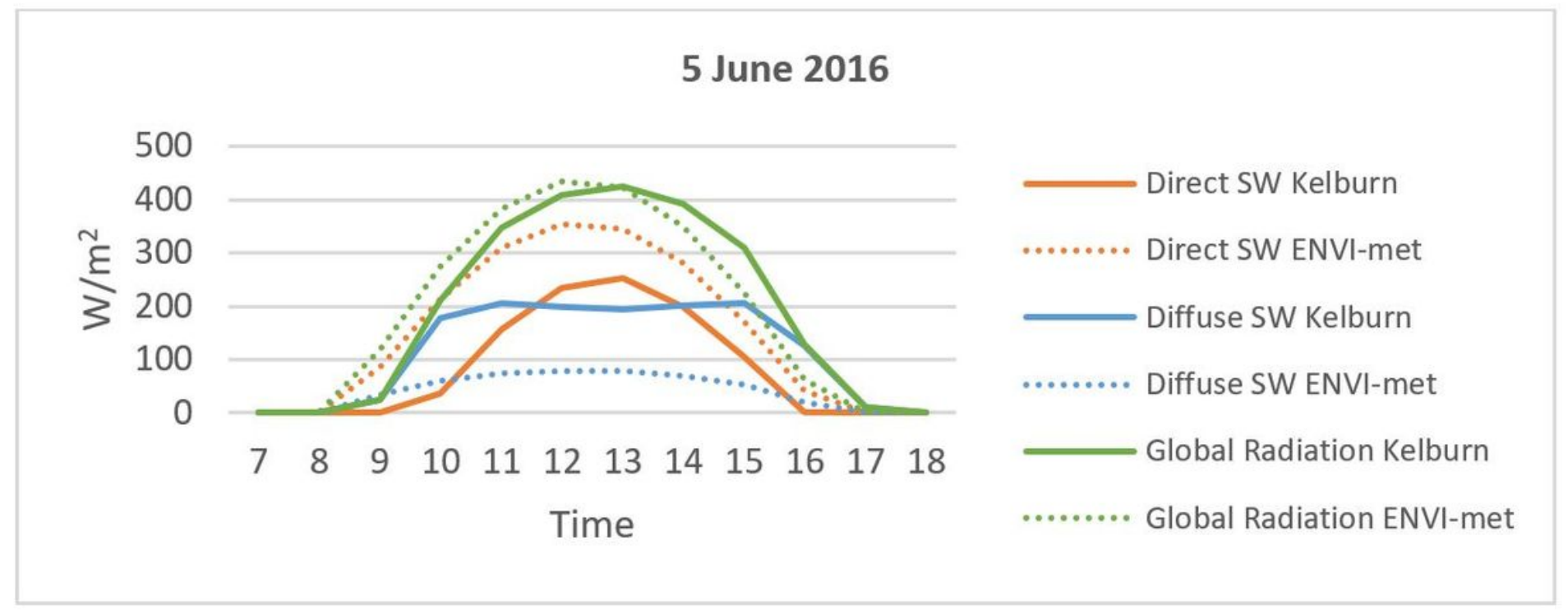

Figure 2

Solar radiation profile between measured data and ENVI-met
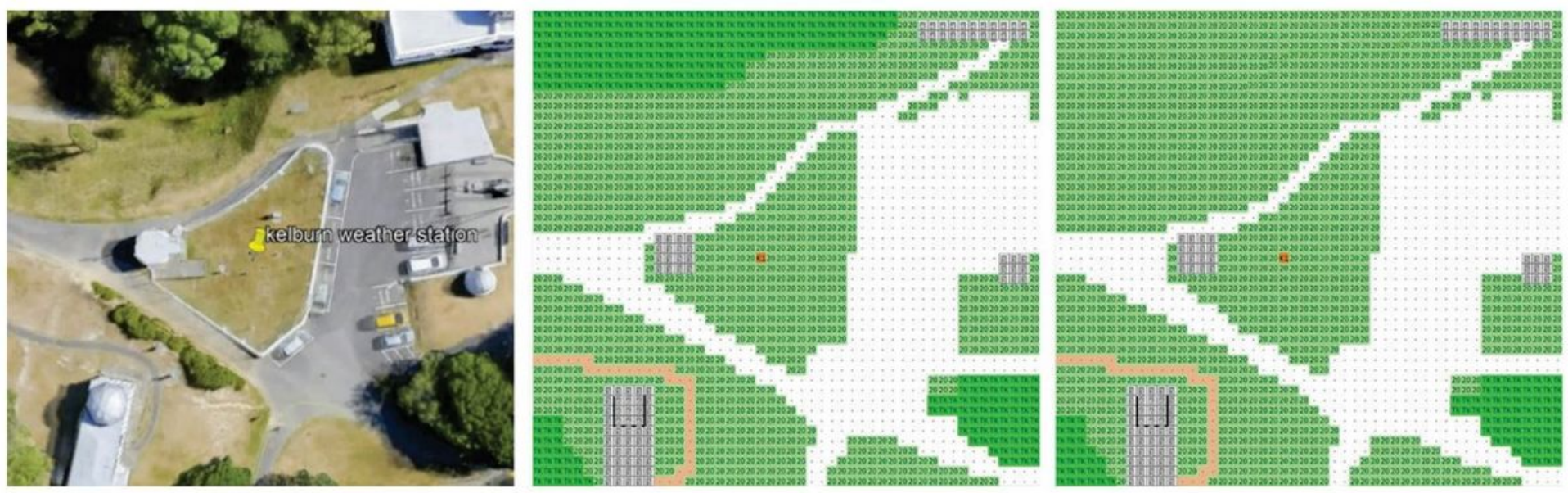


\section{Figure 3}

Left: Real site of Kelburn Weather station (Google Earth); Middle: The Normal model; Right: The Calibrated model

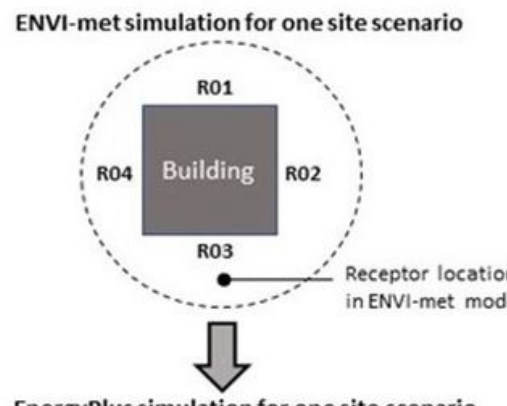

EnergyPlus simulation for one site scenario

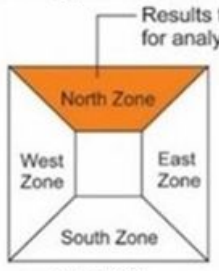

using RO1

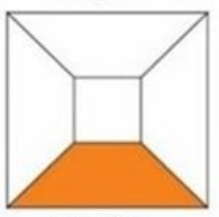

using R03

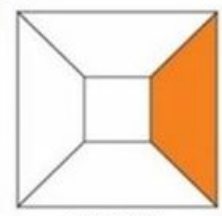

using RO2

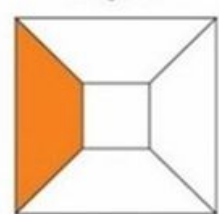

using RO4

EnergyPlus model

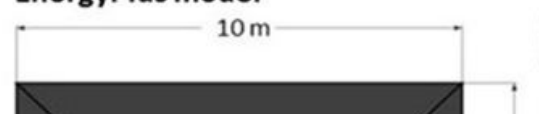

i

Envelope Climate Zone for Wellington

$\begin{array}{ll}\text { Roof } & \text { R } 2.9 \mathrm{~m}^{2} \cdot \mathrm{K} / \mathrm{W}\end{array}$

Wall R $1.9 \mathrm{~m}^{2} \cdot \mathrm{K} / \mathrm{W}$

Floor $\quad \mathrm{R} 1.3 \mathrm{~m}^{2} \cdot \mathrm{K} / \mathrm{W}$

Windows $\quad \mathrm{R} 0.26 \mathrm{~m}^{2} \cdot \mathrm{K} / \mathrm{W}$

\begin{tabular}{|l|l|l|}
\hline $\begin{array}{l}\text { Internal } \\
\text { Load }\end{array}$ & Watt & $\begin{array}{l}\text { Schedule \& } \\
\text { Availability }\end{array}$ \\
\hline Occupancy & $\begin{array}{l}75 \mathrm{~W} \text { per } \\
\text { person }\end{array}$ & $\begin{array}{l}07: 00-23.00(60 \%) \\
23: 00-07.00(100 \%)\end{array}$ \\
\hline Equipment & $16 \mathrm{~W} / \mathrm{m}^{2}$ & $\begin{array}{l}07: 00-23: 00(25 \%) \\
23: 00-07: 00(5 \%)\end{array}$ \\
\hline Lighting & $8.5 \mathrm{~W} / \mathrm{m}^{2}$ & $\begin{array}{l}07: 00-23: 00(15 \%) \\
23: 00-07.00(5 \%)\end{array}$ \\
\hline
\end{tabular}

\begin{tabular}{|l|l|}
\hline Heating Period & April-September \\
\hline Schedule & Full day $(00.00-24: 00)$ \\
\hline Heating set point & $18^{\circ} \mathrm{C}$ \\
\hline $\begin{array}{l}\text { Natural Ventilation } \\
\text { set point }\end{array}$ & $\begin{array}{l}24^{\circ} \mathrm{C} \text { (Open if exceed } \\
\text { setpoint) }\end{array}$ \\
\hline
\end{tabular}

Figure 4

Method for examining the importance of microclimate on energy modelling
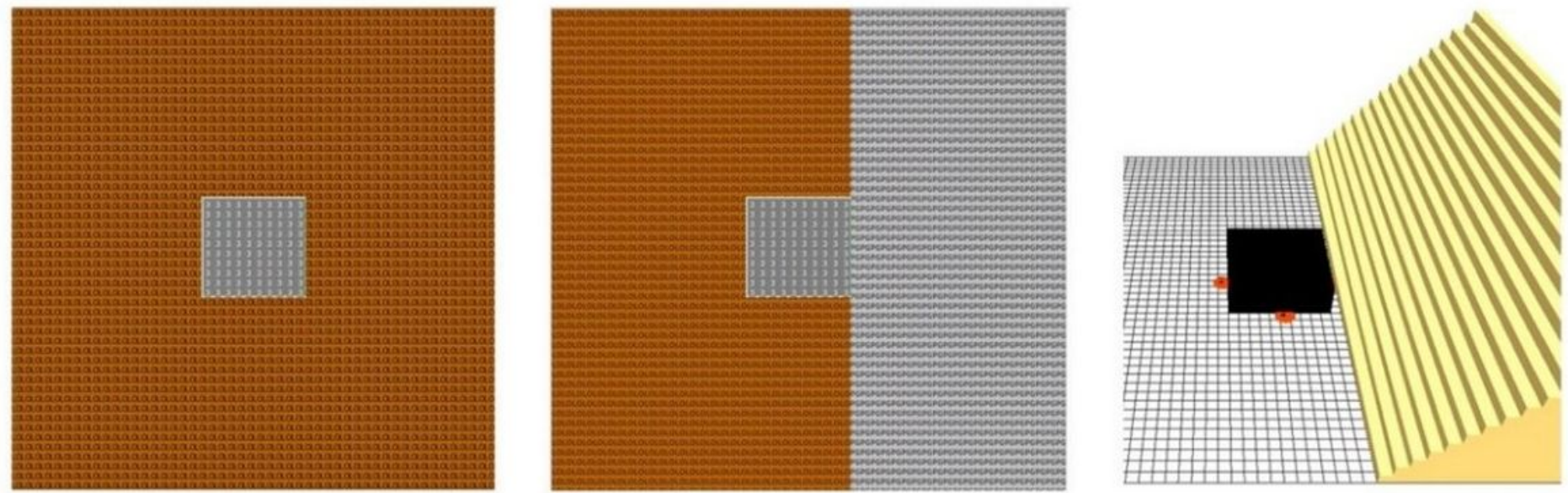

\section{Figure 5}

Site scenarios: The Base model -Loamy soil (1), Pavement on the East side (3) and Facing-north (or south) slope (4) 

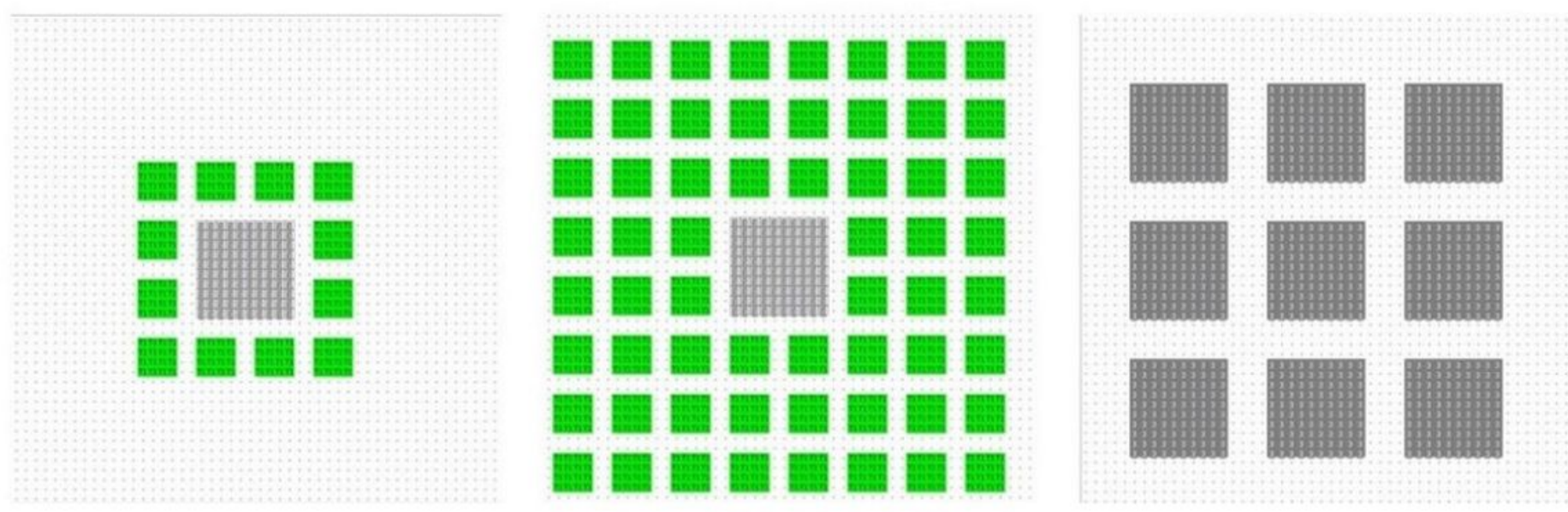

\section{Figure 6}

Site scenarios: 12 trees in all direction (6), 60 trees in all direction (7); and nearby buildings scenarios (9-12)

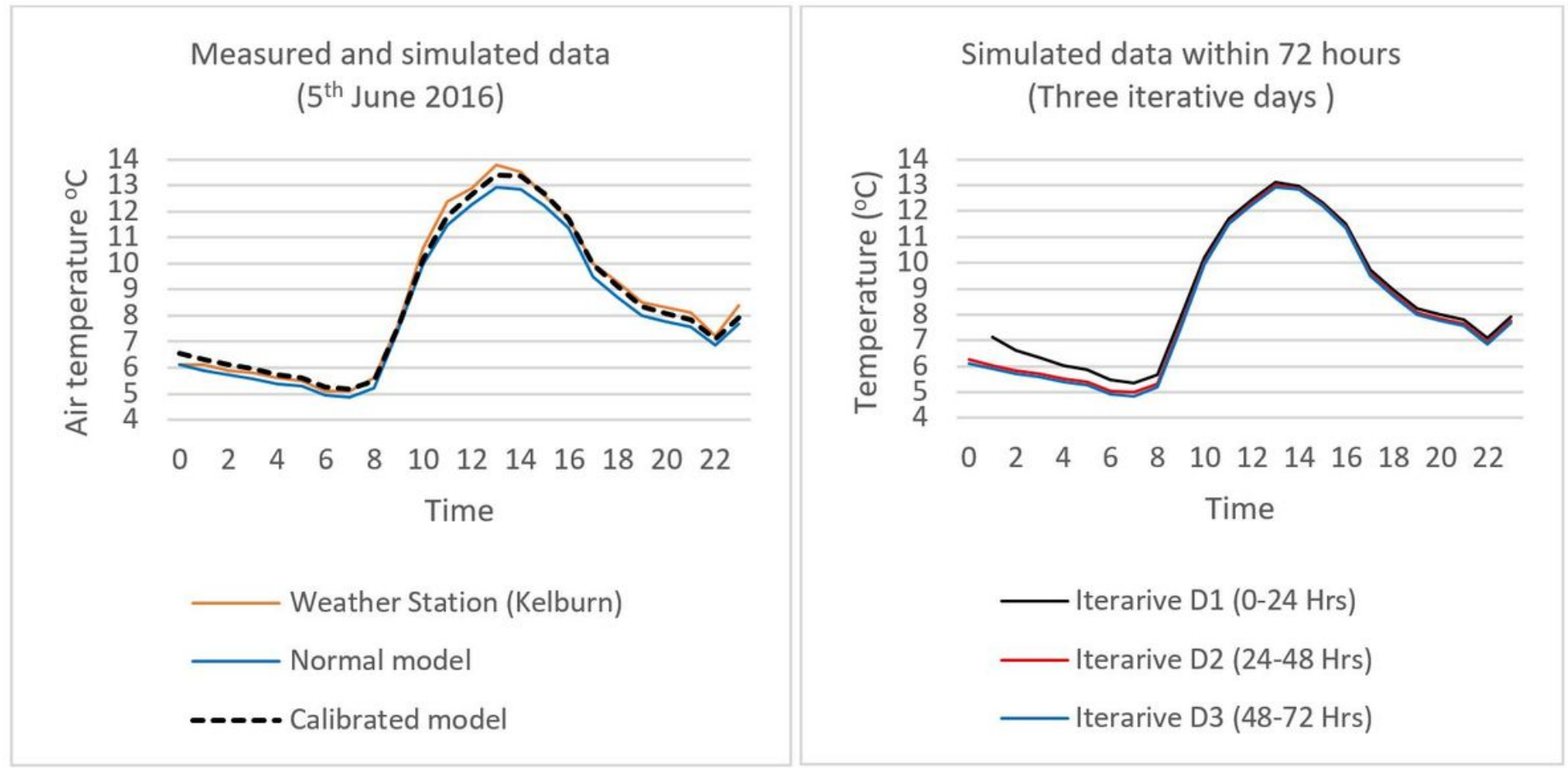

Figure 7

Measured data and simulated data (left) and simulated data on each iterative day within 72 hours 


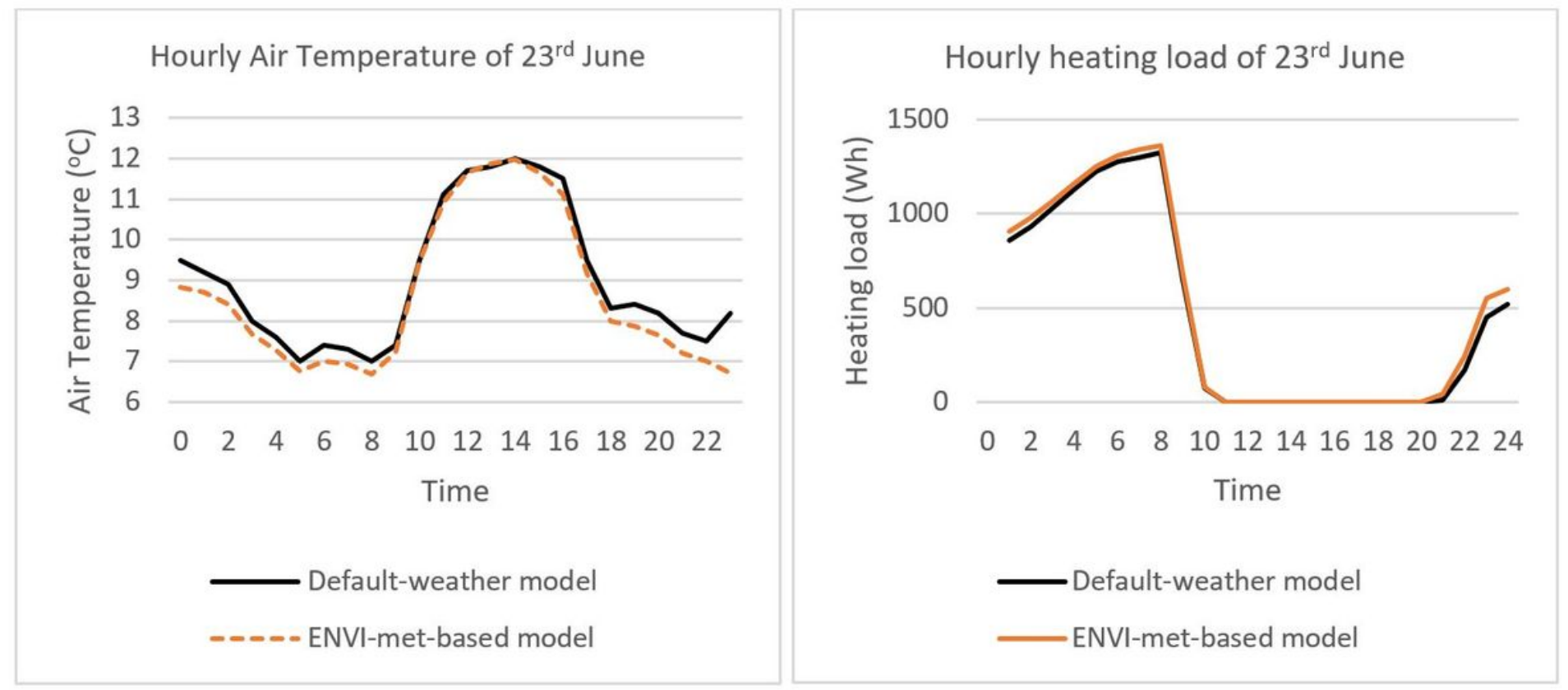

Figure 8

Hourly air temperature and heating load between the default-weather and ENVI-met-based-weather model

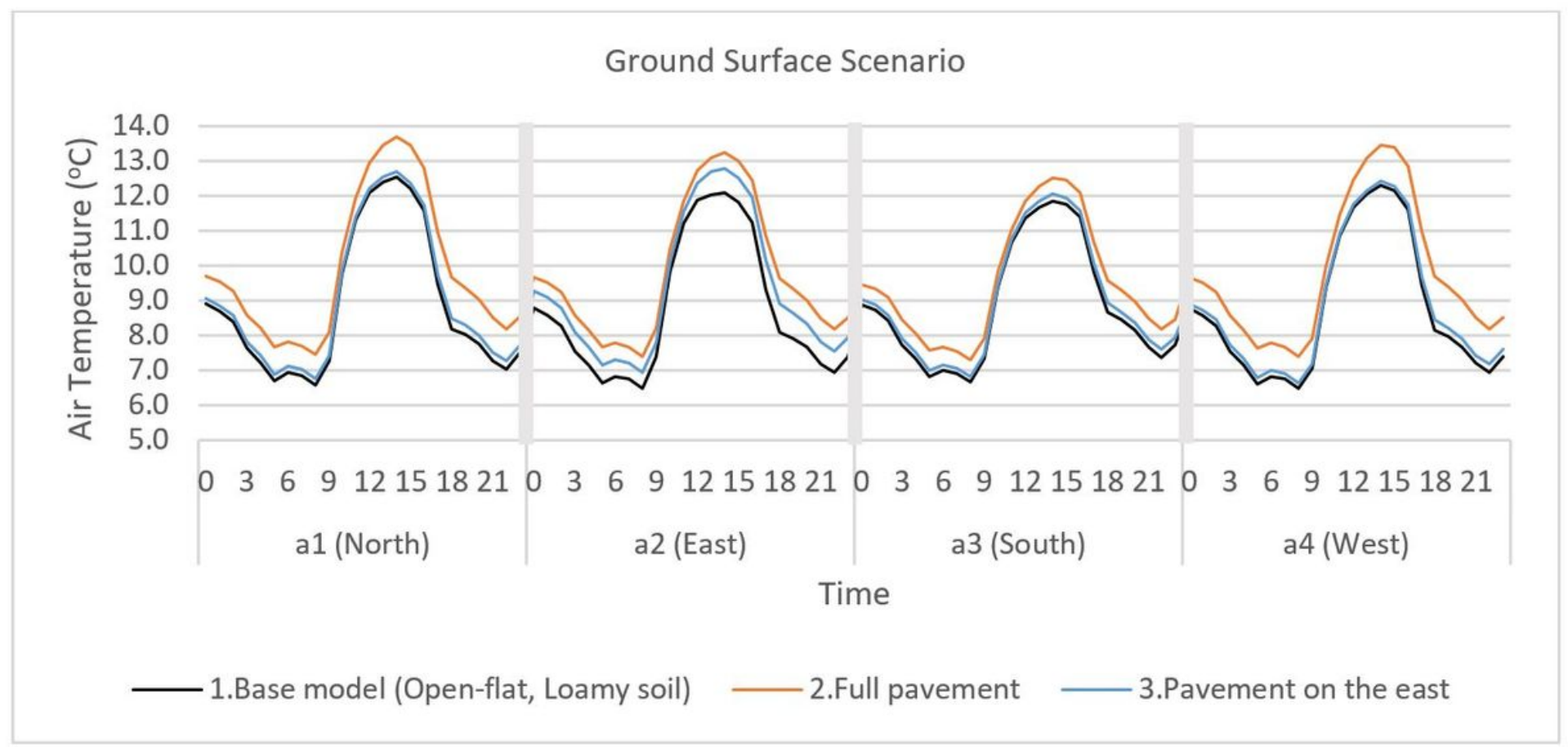

Figure 9

The hourly air temperature of ground surface scenarios 
Slope Surface Scenario
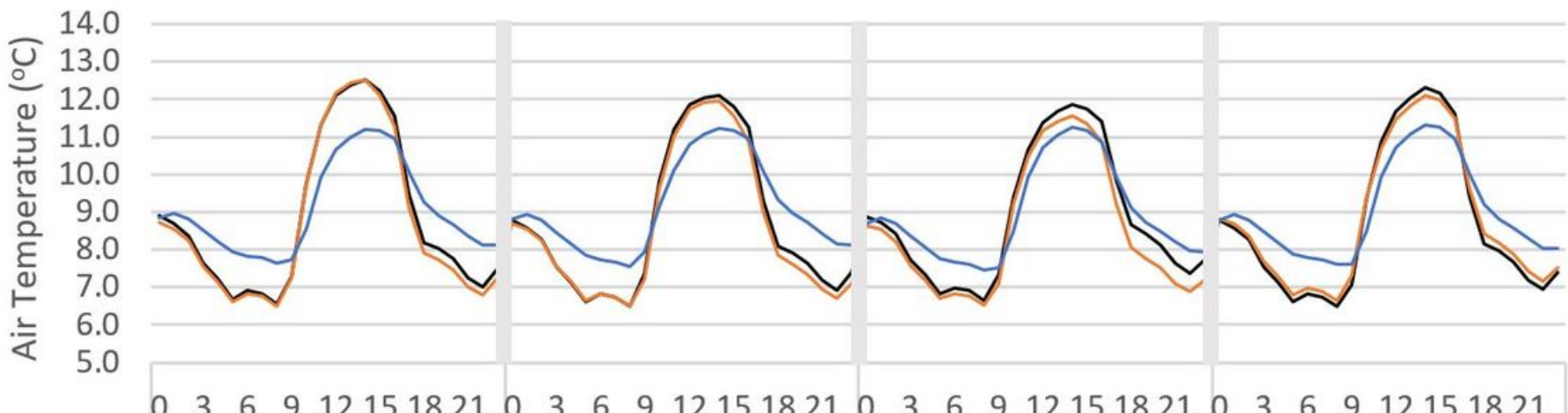
a1 (North)

a2 (East)

a3 (South)

a4 (West)

Time

1.Base model (Open-flat, Loamy soil)

4.Facing-north slope

5.Facing-south slope

\section{Figure 10}

The hourly air temperature of slope scenarios

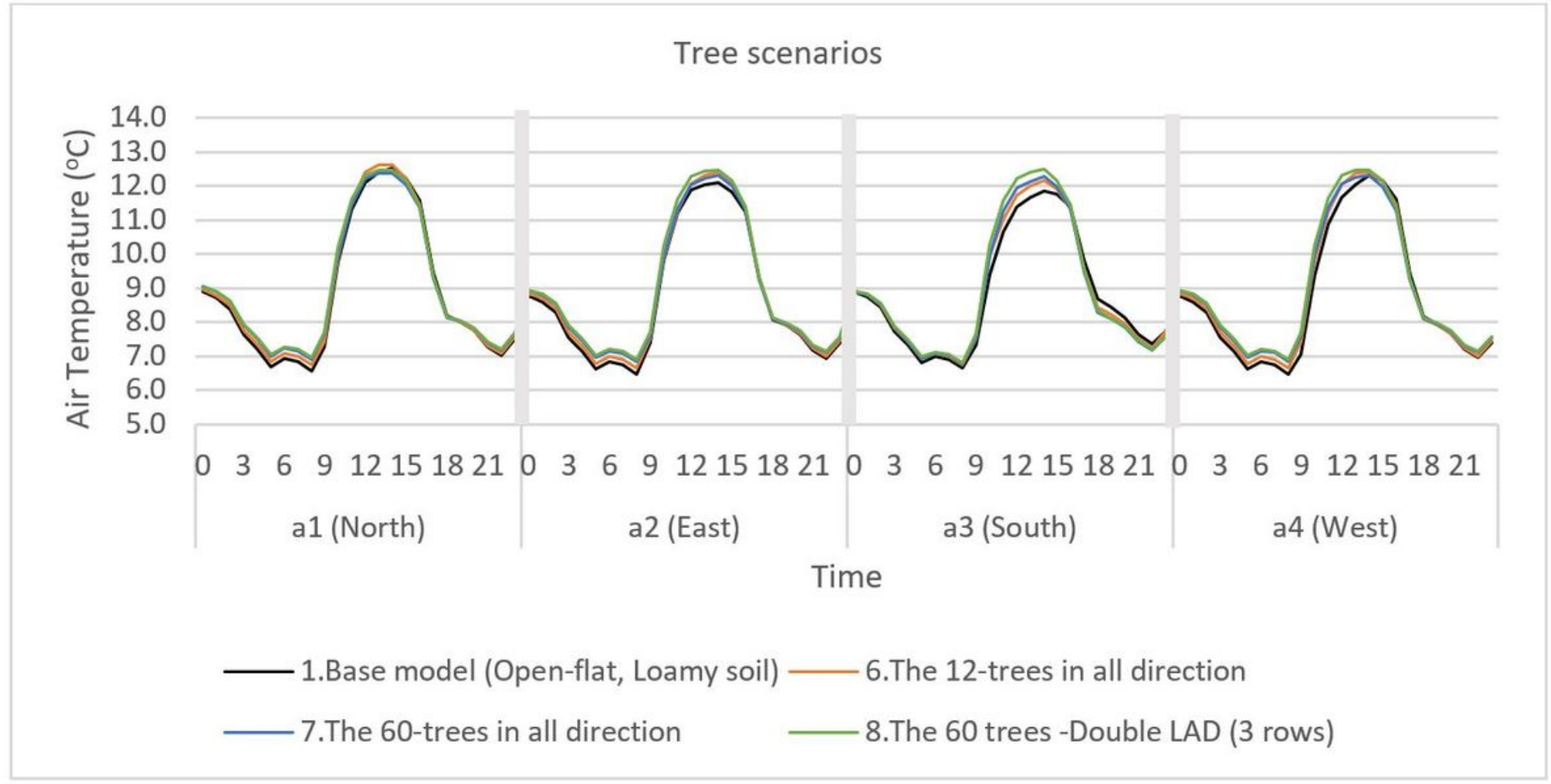

Figure 11

The hourly air temperature of tree scenarios 


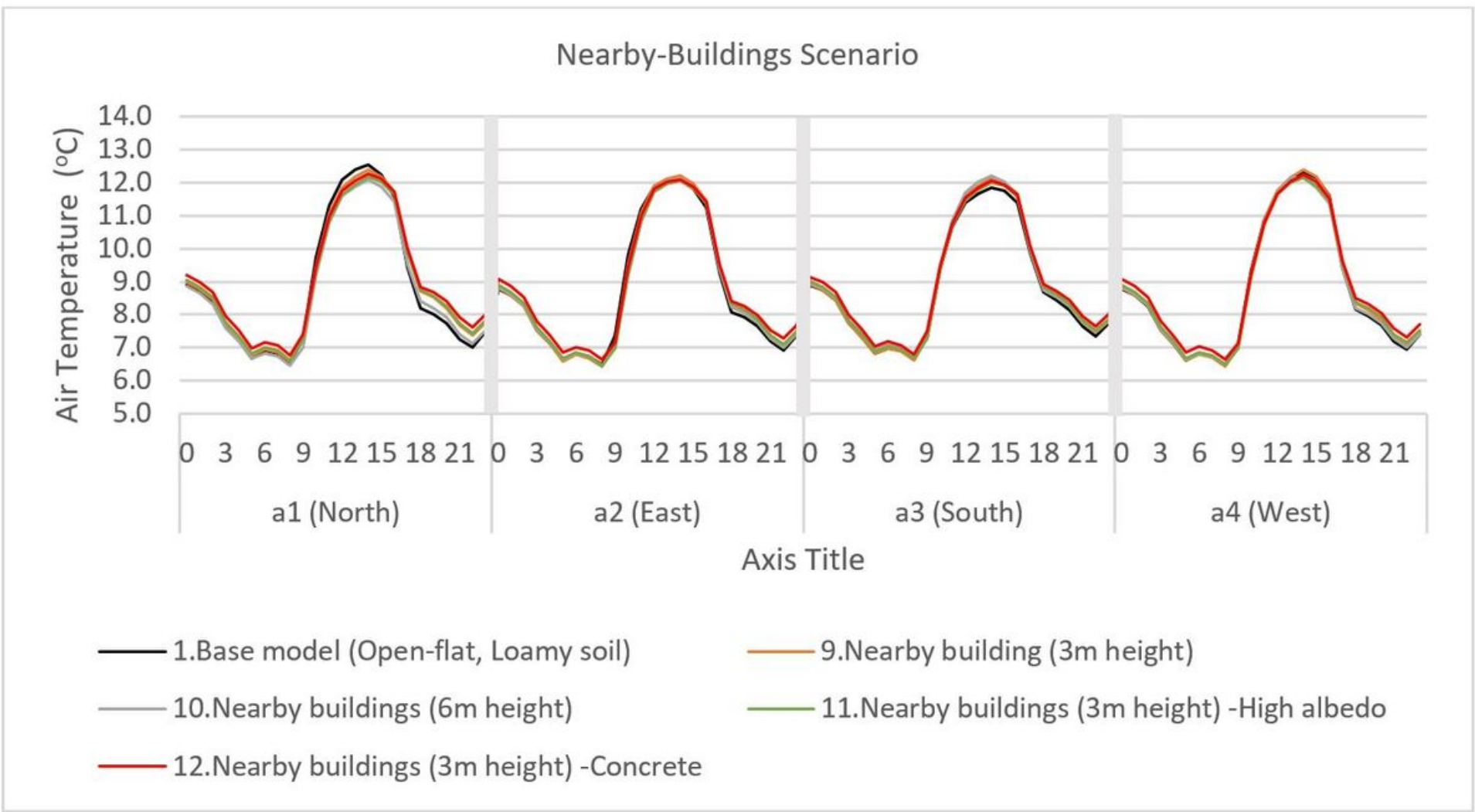

Figure 12

The hourly air temperature of nearby-buildings scenarios 